\title{
Sorption, Desorption, Remediation and Fertility Characteristics of a Clay Soil
}

\author{
Ikrema Hassan $^{1}$ and Eltayeb Mohamedelhassan ${ }^{2}$ \\ 1. Department of Civil and Environmental Engineering, Western University, Ontario N6A 5B9, Canada \\ 2. Department of Civil Engineering, Lakehead University, Ontario P7B 5E1, Canada
}

\begin{abstract}
This study is conducted to investigate sorption and desorption characteristics of a clay soil of Medicine Hat, Alberta, Canada. Also, the soil fertility after the desorption tests was investigated. Sorption of copper by a clay soil was examined using copper solutions with concentrations from $1,000 \mathrm{mg} / \mathrm{L}$ to $5 \mathrm{mg} / \mathrm{L}$. The influence of copper concentration and $\mathrm{pH}$ on desorption was also studied. Electrokinetic remediation was carried on soil specimen spiked with copper. Soil fertility parameters for specimens acidized by electrolysis reactions and nitric, hydrochloric, and citric acids were compared. From the results, the adsorption of copper by the soil is proportional to the concentration in the solution and Langmuir isotherm represents the data. Desorption of copper was found to increase with the increase of initial copper in the soil and the decrease of $\mathrm{pH}$. At $\mathrm{pH}$ of $5.75 \pm 0.25$, the maximum desorption was $16.5 \%$ of initial copper and the minimum was $4.2 \%$. In tests with similar copper concentrations, the maximum desorption was $76.6 \%$ in the test with $\mathrm{pH}$ of 2 . Electrokinetics reduced the $\mathrm{pH}$ of soil near the anode to 2.1 and removed $86 \%$ of copper. Soil specimen acidized by electrolysis reactions preserved favourable fertility parameters compared with specimens acidized by acids.
\end{abstract}

Key words: Sorption, desorption, electrokinetic remediation, fertility.

\section{Introduction}

The sorption and desorption characteristics of soil contaminated with heavy metals are crucial for understanding and evaluating the effectiveness of various remediation techniques. Heavy metals can be defined as elements with specific density greater than $5 \mathrm{~g} / \mathrm{cm}^{3}$ [1]. Contamination of soil with heavy metals poses threat to human and animal's health. The sorption capacity of a soil is essential in estimating fertility and amount of contaminant in the soil solids and that in the soil pore fluid [2,3]. There are numerous sorption sites on the soils having a range of high and low binding energies [4]. For instance, when soil is contaminated with heavy metals of low concentration, the high-energy binding sites are occupied first, while at higher concentrations, the high-energy binding sites are completely occupied and

Corresponding author: Eltayeb Mohamedelhassan, Ph.D., associate professor, research fields: geotechnical and geoenvironmental engineering. E-mail: eltayeb@lakeheadu.ca. the lower-energy binding sites begin to fill, resulting in a decrease in the average metal-soil binding energy. In general, it is easy to remove certain amount of heavy metals from a highly contaminated soil compared with a low contaminated soil because less energy is required to remove contaminants from the former. The hysteresis phenomena in sorption-desorption can be attributed to the binding of heavy metals to the different energy sites [5]. The amount of contaminant adsorbed is also a function of the soil physiochemical properties such as organic matter and $\mathrm{pH}$ [6-8]. Contamination by heavy metals can affect the fertility of the soil [9]. For instance, high copper concentration in soil has an adverse effect in soil fertility by affecting nitrogen fixation $[10,11]$. Desorption of heavy metals from soil matrix to pore fluid is a prerequisite for in-situ and ex-situ soil remediation. In a soil desorption study by Stone and O'Shaughnessy [6], tap water (equivalent to 20 pore volume) was used to leach heavy metals from contaminated soil. The results showed that only $50 \%$ 
of the heavy metals that was sorbed by the soil matrix can be removed. Most heavy metals tend to desorb from soil at low $\mathrm{pH}$ values [12]. A low $\mathrm{pH}$ is achievable by adding acids (organic or inorganic) to the soil or by electrolysis reactions associated with electrokinetics. However, a low pH environment may reduce the soil fertility and prevent maintaining the soil equilibrium [13].

Successful applications of electrokinetic remediation for soil contaminated with heavy metals require understanding of the adsorption and desorption characteristics of the soil for ranges of $\mathrm{pH}$ and metal concentration. The $\mathrm{pH}$ is known to be a dominant factor on the adsorption/desorption behavior of heavy metals by soils [14]. In electrokinetic remediation, electrolysis reactions change the soil $\mathrm{pH}$ and, thereby, influence the adsorption and desorption characteristics.

In this study, copper, a common heavy metal pollutant, was selected and used to investigate the adsorption and desorption characteristics of a clay soil from Medicine Hat, Alberta along with electrokinetic remediation of the soil. The influences of copper concentration and $\mathrm{pH}$ on desorption characteristics of the soil were investigated. The effect of the source of acidity on soil fertility was explored by comparing the fertility parameters for samples acidized by electrolysis reactions, nitric acid, hydrochloric acid and citric acid.

\section{Materials and Methods}

\subsection{Gravimetric Composition}

Copper(II) chloride dihydrate, $\mathrm{CuCl}_{2} \cdot 2 \mathrm{H}_{2} \mathrm{O}$ (molar mass of $170.48 \mathrm{~g} / \mathrm{mol}$ ), was used as the source of copper in the tests. Sodium nitrate, $\mathrm{NaNO}_{3}$ (84.99 $\mathrm{g} / \mathrm{mol}$ ), was used as background electrolyte. Hydrochloric acid $(\mathrm{HCl})$, citric acid $\left(\mathrm{C}_{6} \mathrm{H}_{8} \mathrm{O}_{7}\right)$ and nitric acid $\left(\mathrm{HNO}_{3}\right)$ were used in the soil fertility tests. Solutions with different $\mathrm{pH}$ were prepared by the addition of dilute $\mathrm{HNO}_{3}$ and/or $\mathrm{NaOH}$ solution to water. Deionized water was used in adsorption and desorption tests, and tap water was used in electrokinetic test. Inorganic clay soil obtained from plainsman clay in Medicine Hat, Alberta was used for all the tests. Kaolinite is the predominant clay mineral of the plainsman clay soil. The USCS (unified soil classification system) group symbol for the soil is CL (lean clay). The main properties of the soil are summarized in Table 1. The chemical composition of the soil is shown in Table 2 .

\subsection{Electrokinetic Remediation}

The application of a DC (direct current) electric filed between two electrodes (i.e., anode and cathode) inserted in a moist soil mass establishes an electric potential gradient between the electrodes. This results in electroosmotic flow of water in the soil pores from the anode to the cathode. In addition, it initiates electromigration of ionic species available in the pore fluid towards the oppositely charged electrode.

Along with electroosmosis and electromigration, electrolysis reactions of water occur at the electrodes in an electrokinetic process. The reactions result in

Table 1 Properties of the plainsman clay soil.

\begin{tabular}{ll}
\hline Properties & Values \\
\hline Liquid limit & 41 \\
Plastic limit & 19 \\
Sand (\%) & 0 \\
Silt (\%) & 58 \\
Clay (\%) & 42 \\
Specific gravity & 2.64 \\
Cation exchange capacity & $8.9 \mathrm{meq} / 100 \mathrm{~g}$ \\
\hline
\end{tabular}

Table 2 Chemical composition of the plainsman clay soil.

\begin{tabular}{lc}
\hline Properties & Values \\
\hline $\mathrm{BaO}$ & 0.4 \\
$\mathrm{CaO}$ & 0.2 \\
$\mathrm{~K}_{2} \mathrm{O}$ & 2.2 \\
$\mathrm{MgO}$ & 0.5 \\
$\mathrm{Na}_{2} \mathrm{O}$ & 0.1 \\
$\mathrm{TiO}_{2}$ & 0.6 \\
$\mathrm{Al}_{2} \mathrm{O}_{3}$ & 15.6 \\
$\mathrm{P}_{2} \mathrm{O}_{5}$ & 0.0 \\
$\mathrm{SiO}_{2}$ & 72.7 \\
$\mathrm{Fe}_{2} \mathrm{O}$ & 1.2 \\
$\mathrm{MnO}$ & 0.0 \\
$\mathrm{LOI}$ & $6.5 \%$
\end{tabular}


oxidation at the anode generating an acid front and reduction at the cathode producing a base front:

Anode: $2 \mathrm{H}_{2} \mathrm{O}-4 \mathrm{e}^{-} \rightarrow \mathrm{O}_{2}(\mathrm{~g})+4 \mathrm{H}^{+}(\mathrm{aq})$

Cathode: $2 \mathrm{H}_{2} \mathrm{O}+2 \mathrm{e}^{-} \rightarrow \mathrm{H}_{2}(\mathrm{~g})+2 \mathrm{OH}^{-}$(aq)

The $\mathrm{pH}$ near the anode is reduced due to the generation of hydrogen ions $\left(\mathrm{H}^{+}\right)$, whereas, in the vicinity of the cathode, the $\mathrm{pH}$ is increased by the formation of the hydroxyl ions $\left(\mathrm{OH}^{-}\right)$. The $\mathrm{H}^{+}$ions have smaller size than $\mathrm{OH}^{-}$ions. Accordingly, by electromigration transport, $\mathrm{H}^{+}$ions travel a longer distance towards the cathode than the distance advanced by $\mathrm{OH}^{-}$ions towards the anode. Further, $\mathrm{H}^{+}$ ions also travel by electroosmosis towards the cathode resulting in an acid-base meeting closer to the cathode. The sorption of the cations (Me) with the clay soil surface (S) can be represented by Eq. (3):

$$
\mathrm{S}-\mathrm{OH}+\mathrm{Me}^{2+}+\mathrm{H}_{2} \mathrm{O} \rightarrow \mathrm{S}-\mathrm{O}-\mathrm{MeOH}_{2}^{+}+\mathrm{H}^{+}
$$

\section{Procedures and Equipment}

\subsection{Adsorption of Copper by Soil}

In the adsorption tests, $0.01 \mathrm{M}$ (mole/liter) $\mathrm{NaNO}_{3}$ solution was prepared by adding $0.85 \mathrm{~g}$ of $\mathrm{NaNO}_{3}$ to one liter deionized water. The mixture was thoroughly agitated until $\mathrm{NaNO}_{3}$ was completely dissolved. The $0.01 \mathrm{M} \mathrm{NaNO}_{3}$ solution was used as background electrolyte in the adsorption tests.

Copper solution of concentration $1000 \mathrm{mg} / \mathrm{L}$ was prepared by mixing $0.268 \mathrm{~g}$ of $\mathrm{CuCl}_{2} \cdot 2 \mathrm{H}_{2} \mathrm{O}$ and 100 $\mathrm{mL}$ of the previously prepared $0.01 \mathrm{M} \mathrm{NaNO}_{3}$ solution in $250 \mathrm{~mL}$ Erlenmeyer flask. Six additional solutions with copper concentrations of 500, 250, 100, 50,20 and $5 \mathrm{mg} / \mathrm{L}$ were prepared by successive dilution of the $1,000 \mathrm{mg} / \mathrm{L}$ copper solution. The concentrations of copper solution were selected to achieve a wide range of copper adsorption $(60 \mathrm{mg}$ to $3,700 \mathrm{mg}$ of copper per $\mathrm{kg}$ of dry soil). Seven stopper $50 \mathrm{~mL}$ Erlenmeyer flasks were used in the adsorption tests. A dry soil sample of $1 \mathrm{~g}$ was weighed into each flask. From each of the prepared copper solutions, 14 $\mathrm{mL}$ was measured and added to one of the seven soil samples in the Erlenmeyer flasks.
The soil-solution mixtures were equilibrated at room temperature $\left(21 \pm 1{ }^{\circ} \mathrm{C}\right)$ for $24 \mathrm{~h}$ in a shaking table at $120 \mathrm{rpm}$. The $\mathrm{pH}$ of the soil-solution suspensions was adjusted to $5.75 \pm 0.25$ with nitric acid $\left(\mathrm{HNO}_{3}\right)$ and/or sodium hydroxide $(\mathrm{NaOH})$. The $\mathrm{pH}$ was measured every $2 \mathrm{~h}$ to $3 \mathrm{~h}$ and readjusted when needed. The soil and solutions were then poured into $20 \mathrm{~mL}$ centrifuge tubes. The tubes with the soil and equilibrated suspensions were placed in centrifuge and rotated at 4,000 rpm for $10 \mathrm{~min}$. After that, $1 \mathrm{~mL}$ of the supernatant from each tube was drawn and placed in $20 \mathrm{~mL}$ plastic tube. The solution in each tube was diluted by adding $9 \mathrm{~mL}$ deionized water. The concentrations of the diluted solutions were determined using the ICP-OES (inductively coupled plasma-optical emission spectrometry). Each adsorption test was carried out in triplicate.

\subsection{Desorption of Copper from Soil}

Two sets of tests were conducted to investigate copper desorption from the soil. In the first set, the effects of initial copper concentration on desorption were studied with similar $\mathrm{pH}$. The second set investigated the effects of the $\mathrm{pH}$ on desorption of copper from soil samples with identical initial copper concentration. The selected $\mathrm{pH}$ values were from 2 to 10 , a range that is typically encountered in electrokinetic processes.

3.2.1 Influence of Copper Concentration on Desorption

Desorption tests were performed using soil samples containing different amounts of adsorbed copper with similar $\mathrm{pH}$. The amount of copper desorbed from each soil sample was obtained and compared with the initial amount adsorbed into the sample.

After decanting the solutions from the centrifuge tubes in the adsorption tests as discussed in Section 3.1, the soil samples were used for the desorption tests. For each soil sample (contained $1 \mathrm{~g}$ of dry soil), 14 $\mathrm{mL}$ of $0.01 \mathrm{M} \mathrm{NaNO}_{3}$ solution was added and then the soil and the solution were equilibrated for $24 \mathrm{~h}$ in a 
shaking table at $120 \mathrm{rpm}$ in room temperature $(21 \pm$ $\left.1{ }^{\circ} \mathrm{C}\right)$. The $\mathrm{pH}$ of the soil-solution suspensions was adjusted to $5.75 \pm 0.25$ with nitric acid $\left(\mathrm{HNO}_{3}\right)$ and/or sodium hydroxide $(\mathrm{NaOH})$. The $\mathrm{pH}$ was measured and readjusted every $2 \mathrm{~h}$ to $3 \mathrm{~h}$. After $24 \mathrm{~h}$, the tubes with the soil and the solution mixture were centrifuged at 4,000 rpm for $10 \mathrm{~min}$. From each tube, $1 \mathrm{~mL}$ from the supernatant was drawn and poured in a $20 \mathrm{~mL}$ plastic tube. The solution in the tube was diluted by adding 9 $\mathrm{mL}$ deionized water. The concentrations of copper in the diluted solutions were then determined using ICP-OES. Each test was carried out in triplicate.

\subsubsection{Influence of $\mathrm{pH}$ on Copper Desorption}

Desorption tests were conducted using soil samples with identical copper concentration and different $\mathrm{pH}$ values. The amount of copper desorbed at each $\mathrm{pH}$ was obtained and compared with the initial copper concentration.

The clay soil sample was initially contaminated with $355 \mathrm{mg}$ of copper per $\mathrm{kg}$ of dry soil with water content $41 \%$ (the same copper concentration and water content of the soil specimen used in the electrokinetic remediation test). The soil sample was air-dried for $72 \mathrm{~h}$ and then ground. Five soil samples of $1 \mathrm{~g}$ each were weighted into five Erlenmeyer flasks of $50 \mathrm{~mL}$ volume. $14 \mathrm{~mL}$ of $0.01 \mathrm{M} \mathrm{NaNO}_{3}$ solution was added to each soil sample in the Erlenmeyer flasks. The soil samples with the solution were equilibrated for $24 \mathrm{~h}$ in a shaking table $(120 \mathrm{rpm})$ in room temperature $\left(21 \pm 1{ }^{\circ} \mathrm{C}\right)$. The $\mathrm{pH}$ of the soil-solution suspensions were controlled at values of 2, 4, 6, 8 and 10 with the addition of nitric acid $\left(\mathrm{HNO}_{3}\right)$ and/or sodium hydroxide $(\mathrm{NaOH})$. The $\mathrm{pH}$ was measured every $2 \mathrm{~h}$ to $3 \mathrm{~h}$ and readjusted when needed. The soil and solution was transferred to 20 $\mathrm{mL}$ plastic centrifuge tubes. The tubes with the soil and solution mixture were then centrifuged at 4,000 $\mathrm{rpm}$ for $10 \mathrm{~min}$. After that, $1 \mathrm{~mL}$ of the supernatant from each tube was drawn and placed in $20 \mathrm{~mL}$ plastic tube. Then the solution in each tube was diluted by adding $9 \mathrm{~mL}$ deionized water. The concentrations of the diluted solutions were determined using ICP-OES. Each experiment was repeated three times.

\subsubsection{Electrokinetic Remediation}

Electrokinetic cell was designed and fabricated for the soil remediation test. The electrokinetic cell, constructed of clear plexiglas plates $15 \mathrm{~mm}$ in thickness, has inner dimensions of $385 \mathrm{~mm} \times 125 \mathrm{~mm}$ $\times 250 \mathrm{~mm}$ (length $\times$ width $\times$ height $)$. The cell is composed of upper part, base and two movable rectangular perforated plexiglas plates $(250 \mathrm{~mm}$ length $\times 125 \mathrm{~mm}$ width). The upper part forms an outer boundary to accommodate the soil sample. The rectangular plexiglas plates can be used to adjust the soil sample length between $200 \mathrm{~mm}$ and $320 \mathrm{~mm}$. The base of the cell is detachable to allow for easy recovery and minimum disturbance of the soil specimen that is to be used for subsequent parametric studies. At the base far ends, two drainage valves were installed and used to collect water during the remediation process. Fig. 1 shows the electrokinetic remediation cell.

The soil specimen for electrokinetic remediation test was prepared in batches. For each batch, $5 \mathrm{~kg}$ of dry plainsman clay soil was weighed into a plastic pail. $2,050 \mathrm{~mL}$ of tap water (required for water content of $41 \%$ similar to the liquid limit of the soil) was poured into a container. To investigate the effectiveness of electrokinetics in remediating soil contaminated with a heavy metal, the plainsman clay soil was spiked with copper at concentration of $355 \mathrm{mg} / \mathrm{kg}$ of dry soil. $4.77 \mathrm{~g}$ of copper(II) chloride dehydrate was thoroughly mixed with the water in the container. The dry soil and the copper solution were mixed using a mechanical mixer. Additional batches were similarly prepared. The soft contaminated soil was poured into a thick plastic bag and placed in a pail with airtight cover. The soil was stored to allow for copper adsorption by soil to take place and reach equilibrium. $72 \mathrm{~h}$ after preparing the pre-contaminated soil, the soil was placed into the electrokinetic cell in three layers for a total height of $165 \mathrm{~mm}$. Each layer was rodded 


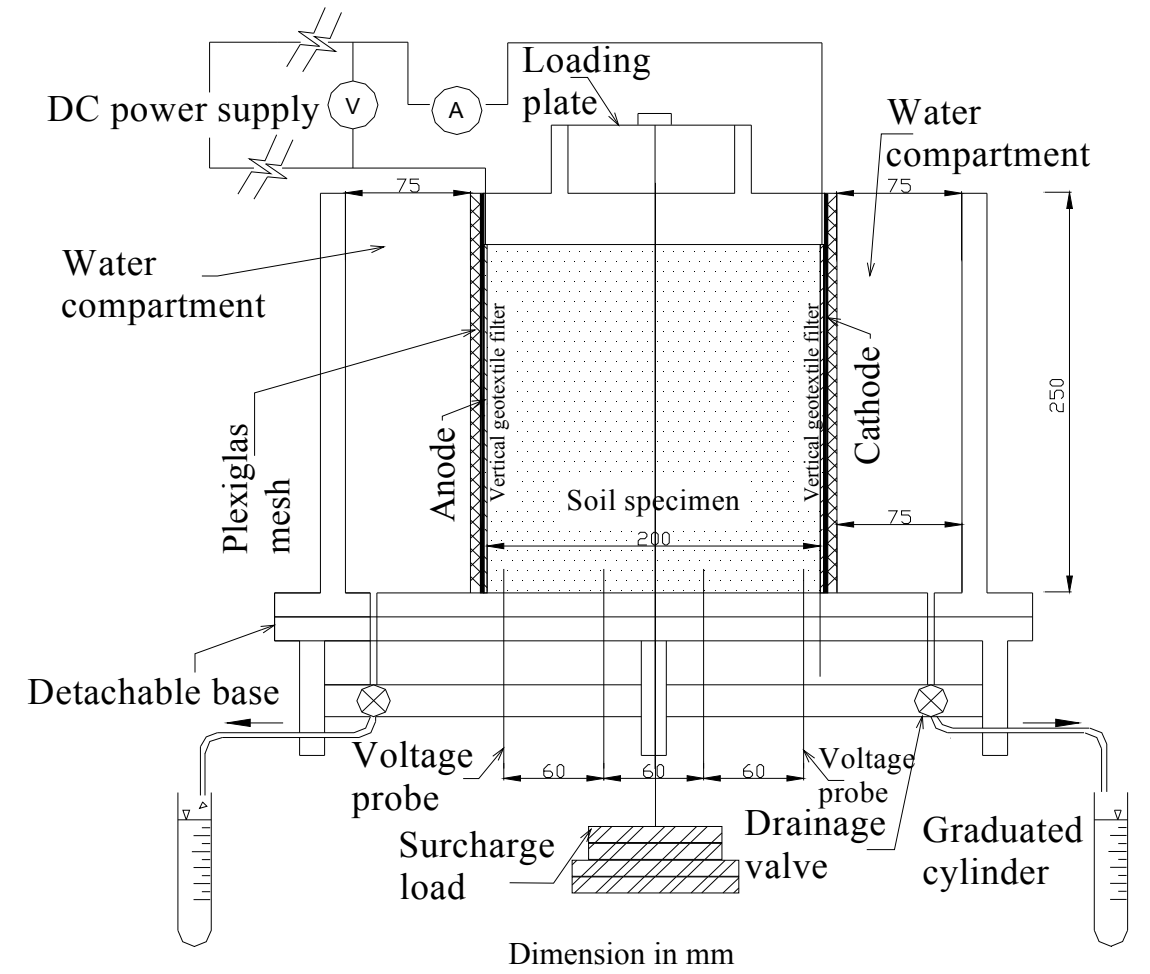

Fig. 1 Schematic diagram for electrokinetic cell.

25 times using steel rod, $16 \mathrm{~mm}$ in diameter and 600 $\mathrm{mm}$ long with a hemispherical shaped tip, to prevent the entrapment of air pockets. The high water content of the soil and the thorough rodding during placement insured that the soil specimen was nearly, if not fully, saturated. A surcharge load of $12.8 \mathrm{~kg}$ (corresponding to a pressure of $5 \mathrm{kPa}$ ) was applied to the soil via the loading plate in four increments over a period of four days. The first surcharge load was $0.6 \mathrm{~kg}$, followed by $3 \mathrm{~kg}, 5 \mathrm{~kg}, 7.8 \mathrm{~kg}$ and $12.8 \mathrm{~kg}$. Graphite (nonmetallic) was selected as electrode material to avoid/minimize adverse reactions by-products of metallic electrode. Two perforated graphite electrodes, one serving as anode and the other as cathode with dimensions of $200 \mathrm{~mm} \times 125 \mathrm{~mm} \times 3 \mathrm{~mm}$ (height $\times$ width $\times$ thickness), were placed in direct contact with the soil. A geotextile filter was wetted by tap water and placed between the electrode and the plexiglas. The electric filed was provided by a solar cell panel with peak outputs of $41 \mathrm{~V}$ and $5 \mathrm{~A}$ connected to the graphite electrodes in the electrokinetic cell. The corresponding applied voltage gradient across the cell was $205 \mathrm{~V} / \mathrm{m}$. The experiment was carried out in July 3, 2010 for a period of seven days.

\subsection{Soil Fertility}

Tests were carried out to compare the effect of acidification by electrolysis reactions and by the addition of acidic chemical compounds on the fertility characteristic of the plainsman clay soil. In the chemical compound tests, the $\mathrm{pH}$ of the soil was lowered to $2.25 \pm 0.25$, similar to the $\mathrm{pH}$ values encountered near the anode in an electrokinetic remediation process. The chemical compounds used in the tests were hydrochloric, citric and nitric acids. Three soil samples contaminated (355 mg of copper per kg of dry soil) were acidified using the acids. The acidified soil samples along with soil sample near the anode in the electrokinetic test were analyzed at the FoReST (Forest Recourse and Soil Testing) Laboratory, Lakehead University for fertility characteristics. OMAFRA (Ontario Ministry of 
Agriculture, Food and Rural Affairs), fertilizer recommendations chart to optimize plant growth was used to obtain the amount of lime required for the soil.

\section{Results and Discussion}

\subsection{Adsorption of Copper}

Adsorbed copper was calculated as the difference between the amount initially present in the solution and the amount remaining in solution after equilibration. The results were used to determine the parameters for both Langmuir and Freundlich sorption models. The Langmuir isotherm was found to best represent the data. Langmuir equation is given by Langmuir [15]:

$$
\frac{C_{e}}{S}=\frac{1}{K_{L} M_{L}}+\frac{C_{e}}{M_{L}}
$$

where, $C_{e}(\mathrm{mg} / \mathrm{L})$ is the equilibrium copper concentration in the supernatant, $S(\mathrm{mg} / \mathrm{g})$ is the amount of copper adsorbed by the soil, $K_{L}(\mathrm{~L} / \mathrm{mg})$ is the Langmuir constant and $M_{L}(\mathrm{mg} / \mathrm{g})$ is the Langmuir maximum adsorption capacity of the soil.

$$
\begin{gathered}
C_{e 1}=\frac{C_{e 1}+C_{e 2}+C_{e 3}}{3} \\
S=\frac{\left(C_{i}-C_{e}\right)}{\left(M_{s}\right)} \times 14 \mathrm{~mL} \times \frac{1 \mathrm{~L}}{1,000 \mathrm{~mL}}
\end{gathered}
$$

where, $C_{e 1}, C_{e 2}$ and $C_{e 3}(\mathrm{mg} / \mathrm{L})$ are equilibrium copper concentration in the supernatant in Tests 1, 2 and 3, and $C_{i}(\mathrm{mg} / \mathrm{L})$ is the initial copper concentration in the solution (e.g., 1,000 mg/L) and $M_{s}$ is the mass of dry soil in grams.

Langmuir equation parameters were obtained from Fig. 2 which shows $C_{e} / S$ (ratio of copper concentration in the supernatant to copper adsorbed into the soil) vs. copper concentration in the supernatant $\left(C_{e}\right)$. Fig. 2 also shows the amount of adsorbed copper $(S)$ vs. copper concentration in the supernatant $\left(C_{e}\right)$. From Fig. 2, $S$ increased with the increase of the $C_{e}$. The results obtained from this test showed similar adsorption behavior to that reported by Yuan et al. [14] on kaolin clay.

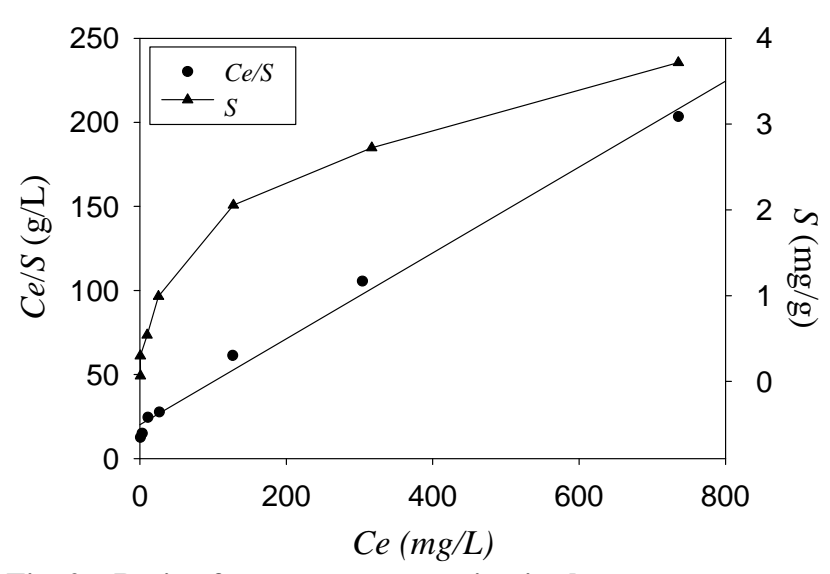

Fig. 2 Ratio of copper concentration in the supernatant to copper adsorbed into the soil $\left(C_{e} / S\right)$ and copper adsorbed into the soil $(S)$ vs. copper concentration in the supernatant $\left(C_{e}\right)$.

Table 3 Langmuir isotherm equation.

\begin{tabular}{llll}
\hline Regression equation & Coefficient $R^{2}$ & $K_{L} L / \mathrm{mg}$ & $M_{L} \mathrm{mg} / \mathrm{g}$ \\
\hline$C_{e} / S=0.25 C_{e}+19.22$ & $R^{2}=0.988$ & 0.013 & 3.98 \\
\hline
\end{tabular}

Table 3 presents Langmuir equation, Langmuir constant $\left(K_{L}\right)$ and the maximum adsorption capacity of the soil $\left(M_{L}\right)$. From the results of the adsorption test, the Langmuir equation for the soil is given by:

$$
\frac{C_{e}}{S}=19.22+0.2508 C_{e}
$$

\subsection{Desorption of Copper}

\subsubsection{Effect of Copper Concentration on Desorption}

The amount of copper desorbed from the soil was calculated as follows:

$$
\begin{gathered}
D_{e}=\frac{\left(D_{\text {ave }}-C_{i}\right) \times V I}{\left(M_{s}\right)} \times \frac{1,000 \mathrm{~g}}{\mathrm{~kg}} \\
D_{\text {ave }}=\frac{D_{1}+D_{2}+D_{3}}{3}
\end{gathered}
$$

where, $D_{e}(\mathrm{mg} / \mathrm{kg})$ is the desorbed copper, $D_{\text {ave }}(\mathrm{mg} / \mathrm{L})$ is the average desorption equilibrium copper concentration in the supernatant, $D_{1}, D_{2}$ and $D_{3}(\mathrm{mg} / \mathrm{L})$ are desorption equilibrium copper concentrations in the supernatant in Tests 1,2 and 3, respectively, $C_{i}$ $(\mathrm{mg} / \mathrm{L})$ is the initial copper concentration in the solution ( $C_{i}$ in the sodium nitrate solution was zero), and $V I(\mathrm{~L})$ is the volume of sodium nitrate solution added to the soil sample ( $V I=0.014 \mathrm{~L}$ ). 
The desorbed copper $\left(D_{e}\right)$ was plotted against the initial adsorbed copper $(S)$ in Fig. 3. The experiments covered a range of the adsorbed copper between 60 $\mathrm{mg}$ and 3,700 $\mathrm{mg}$ per $\mathrm{kg}$ of dry soil (Table 4). For the range tested, Fig. 3 shows that the desorbed copper increases with the increase of the initial adsorbed copper. The highest copper desorbed $(670 \mathrm{mg} / \mathrm{kg})$ was obtained for the adsorbed amount of 3,700 mg/kg. For adsorbed copper $<1,000 \mathrm{mg} / \mathrm{kg}$ of dry soil, the slope of desorption profile is somewhat flat, whereas, for initial adsorbed copper $>1,000 \mathrm{mg} / \mathrm{kg}$, the profile slope is steeper. The percentage of desorbed copper to the initial adsorbed copper was calculated for each test and Fig. 4 shows ratio (in percentage) of desorbed copper to the initial adsorbed copper $\left(D_{e} / S\right)$ vs. initial adsorbed copper $(S)$. As seen in Fig. 3 in general, $D_{e} / S$ increases with the increase of $S$. The highest and lowest $D_{e} / S$ percentages were $16.5 \%$ and $4.2 \%$ reported

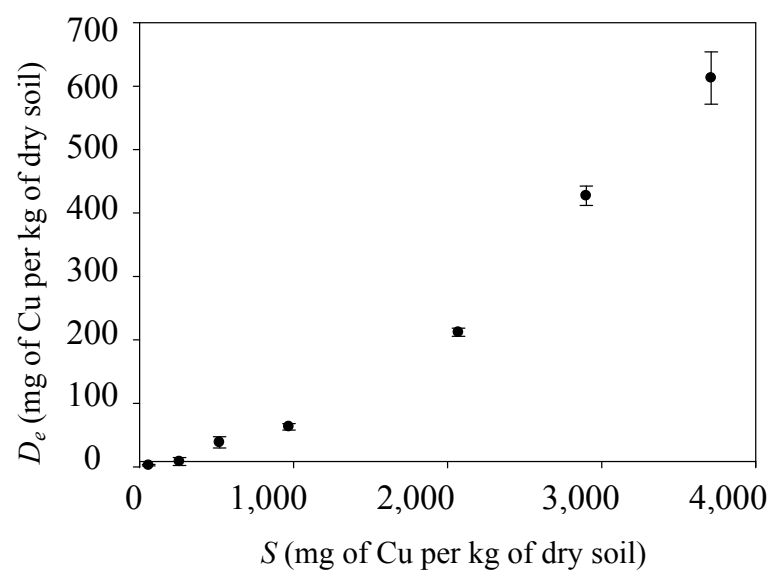

Fig. 3 Desorbed copper $\left(D_{e}\right)$ vs. initial adsorbed copper $(S)$ at $\mathrm{pH}$ of $5.75 \pm 0.25$.

Table 4 Sorption test results.

\begin{tabular}{lll}
\hline $\begin{array}{l}\text { Initial } \mathrm{Cu} \\
\text { concentration } \\
(\mathrm{mg} / \mathrm{L})\end{array}$ & $\begin{array}{l}\text { Equilibrium } \mathrm{Cu} \\
\text { concentration } \\
(\mathrm{mg} / \mathrm{L})\end{array}$ & $\begin{array}{l}\text { Amount adsorbed } \\
(\mathrm{mg} / \mathrm{kg})\end{array}$ \\
$C_{i}$ & $C_{\mathrm{ave}}=C_{e}$ & $S$ \\
\hline $1,001.00$ & 735.70 & 3,710 \\
511.20 & 304.10 & 2,900 \\
274.50 & 126.83 & 2,070 \\
96.21 & 26.76 & 970 \\
48.43 & 10.96 & 520 \\
21.70 & 3.19 & 260 \\
5.33 & 0.80 & 60 \\
\hline
\end{tabular}

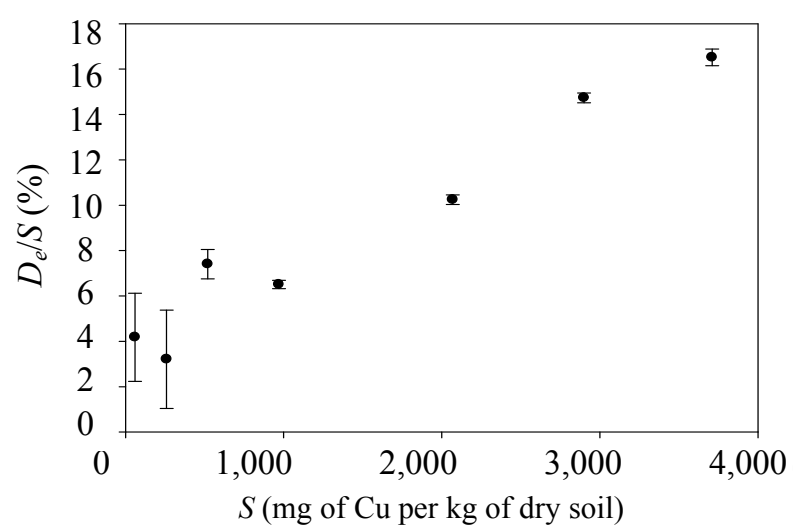

Fig. 4 Ratio (in percentage) of desorbed copper to the initial adsorbed copper $\left(D_{e} / S\right)$ vs. initial adsorbed copper $(S)$ at $\mathrm{pH}$ of $5.75 \pm 0.25$

with the tests with initial adsorbed copper of 3,700 $\mathrm{mg} / \mathrm{kg}$ and $60 \mathrm{mg} / \mathrm{kg}$, respectively.

\subsubsection{Effect of $\mathrm{pH}$ on Copper Desorption}

Fig. 5 shows the amount of desorbed copper at different $\mathrm{pH}$ values. The figure shows that the amount of desorbed copper decreases as the $\mathrm{pH}$ increases. For instance, for soil sample with $\mathrm{pH}$ of 2 , the amount of desorbed copper was $270 \mathrm{mg} / \mathrm{kg}$ of dry soil compared to $180 \mathrm{mg} / \mathrm{kg}$ at $\mathrm{pH}$ of 4 . Fig. 5 shows that very little or no copper was desorbed at $\mathrm{pH} \geq 8$. Fig. 6 shows the ratio in percentages of copper desorbed to the initial copper in the soil (355 $\mathrm{mg}$ copper per kg of dry soil) at different $\mathrm{pH}$ values. At low $\mathrm{pH}$ values (i.e., $\mathrm{pH}$ of 2 and 4), the percentages of copper desorption were $76.6 \%$ and $50 \%$, while at $\mathrm{pH}>8$ (alkaline medium), virtually no copper was desorbed from the soil.

It has been reported in the literature that, in general, the rise of $\mathrm{pH}$ results in more adsorption of heavy metals by soils and vice versa $[14,16,17]$. Therefore, it can be concluded that, for the clay soil and the range of copper concentrations tested in this study, desorption of copper increases with the decrease of $\mathrm{pH}$. The maximum desorbed copper was $76.6 \%$ of the initial concentration reported in the test with $\mathrm{pH}$ of 2 . In an electrokinetic remediation process, the desorbed copper will be free in the pore fluid and available to be removed from the soil by electroosmosis and electromigration. 


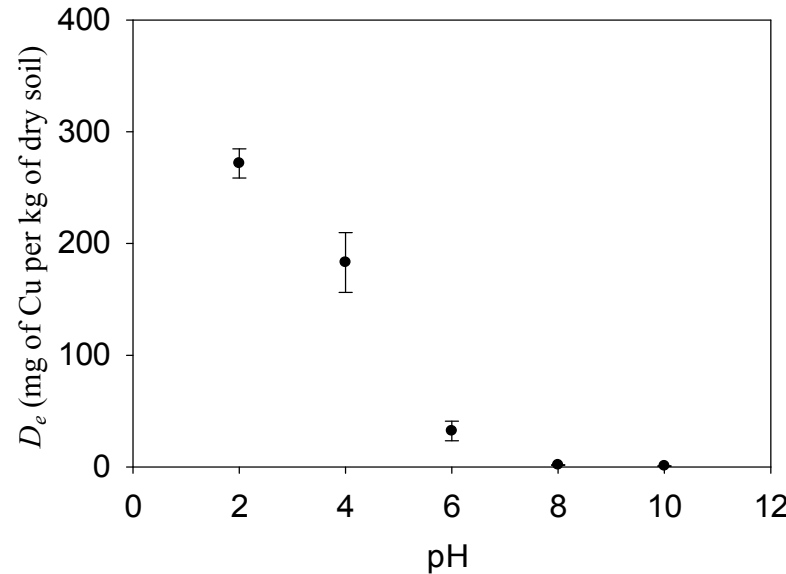

Fig. 5 Desorbed copper $\left(D_{e}\right)$ vs. $\mathrm{pH}$ for soil samples with initial copper concentration of $355 \mathrm{mg} / \mathrm{kg}$.

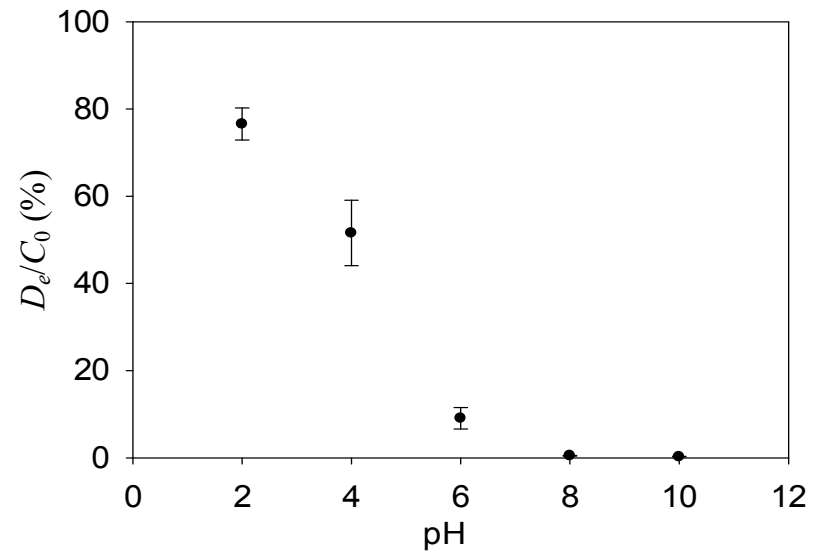

Fig. 6 Ratio (in percentage) of desorbed copper to initial copper in soil $\left(D_{e} / C_{o}\right)$ vs. pH for soil with $C_{o}$ of $355 \mathrm{mg} / \mathrm{kg}$.

\subsection{Electrokinetic Remediation}

After the electrokinetic remediation test, the soil in the electrokinetic cell was divided into four equal sections. Fig. 7 shows the $\mathrm{pH}$ along the soil after the test. $D$ is the horizontal distance between the mid of the soil section and the anode. $D_{o}$ is the total length of the soil sample $(200 \mathrm{~mm})$. Thus, $0.1 \mathrm{D} / \mathrm{D}_{\mathrm{o}}$ is the soil section near the anode while $0.9 D / D_{0}$ is the section near cathode. As shown in the figure, $60 \%$ of the soil reported $\mathrm{pH}<3.5$ (i.e., acidic) with the lowest $\mathrm{pH}$ near the anode (2.1). The remaining $40 \%$ of the soil had $\mathrm{pH}>7$ and the highest $\mathrm{pH}$ was 8.9 near the cathode. The $\mathrm{pH}$ profiles are in agreement with the electrolysis reactions at the electrodes and the distance travelled by the $\mathrm{H}^{+}$and $\mathrm{OH}^{-}$ions.

Fig. 8 shows the ratio (in percentage) of the copper concentration after the electrokinetic test to the initial concentration of $355 \mathrm{mg} / \mathrm{kg}$ of dry soil along the electrokinetic cell. The concentrations are presented for the total copper in the soil, copper in soil solids and copper in pore fluid. The figure clearly shows that electrokinetics was generally effective in moving copper from the soil near the anode towards the cathode. The movement of copper was due to the combined effects of electroosmosis and electromigration along with the change in the soil $\mathrm{pH}$ during the process. The lowest ratio of the copper concentration after the test to the initial concentration was $14 \%$ in the soil section near the anode $\left(0.1 \mathrm{D} / \mathrm{D}_{\mathrm{o}}\right)$. Thus, $86 \%$ of the initial copper was removed from the soil near the anode. The copper concentration increased toward the cathode with the maximum concentration of $256 \%$ at $0.7 \mathrm{D} / \mathrm{D}_{\mathrm{o}}$ (the soil section the

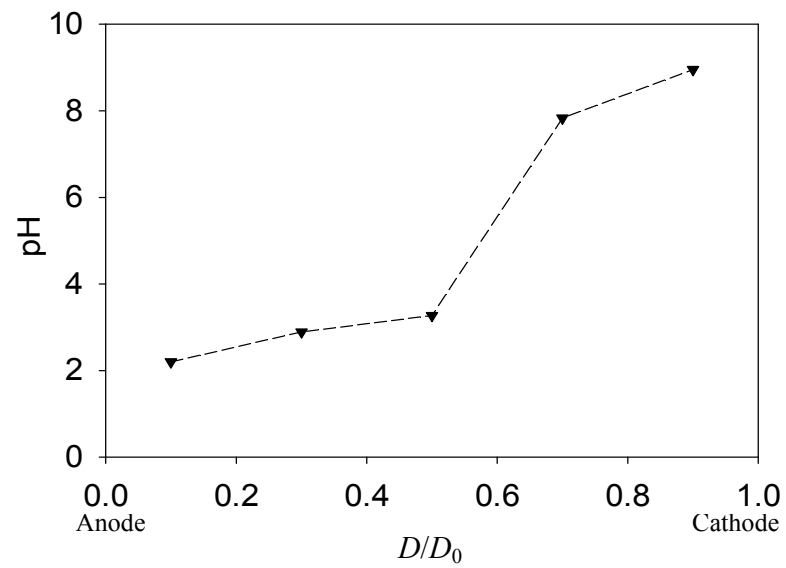

Fig. 7 pH of the soil vs. normalized distance between the anode and cathode $\left(D / D_{0}\right)$.

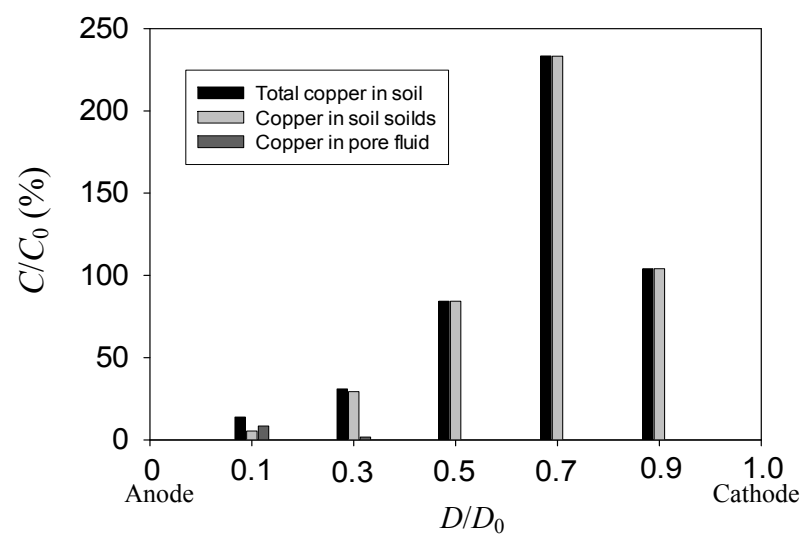

Fig. 8 Ratio of copper concentration at the end of test to initial copper concentration $\left(C / C_{0}\right)$ vs. normalized distance between the anode and cathode $\left(D / D_{0}\right)$. 
acid and base fronts met). As seen in Fig. 8, the highest ratio of copper in the pore fluid was observed near the anode and the ratio decreased towards the cathode. This resulted from the low $\mathrm{pH}$ near the anode which promotes copper dissolution while the high $\mathrm{pH}$ at the cathode caused copper precipitation.

In the electrokinetic test, the high copper removal (86\% of initial copper) from soil section at $0.1 \mathrm{D} / \mathrm{D}_{\mathrm{o}}$ coincided with lowest soil $\mathrm{pH}$ reported in the soil (2.1). On the other hand, in the desorption test at approximately the same $\mathrm{pH}$ (2), the amount of desorbed copper was $76.6 \%$ of the initial copper. This means that the copper removal by electrokinetic was higher than that by the desorption test. This is attributed to the electromigration. The dominance role of electromigration is removing copper which is in agreement with previous studies by Page and Page [18] and Probstein and Hicks [19]. Acar et al. [20] had successfully removed cadmium without electroosmosis flow. Therefore, any copper removal higher than $76.6 \%$ achieved by electrokinetic remediation can be attributed to removal by electromigration. As per the results, for clay soil contaminated with copper at $355 \mathrm{mg} / \mathrm{kg}$, the use of conventional soil flushing with solution 14 times the mass of the soil, $\mathrm{pH}$ of 2 and $24 \mathrm{~h}$ of agitation, can remove $76.6 \%$ of the initial copper. Obviously, this will be very expensive and impractical for full-scale applications.

\subsection{Soil Fertility}

The results of the fertility parameters of the soil after acidification are shown in Table 5. For a soil with high acidity ground, limestone is added to raise the $\mathrm{pH}$ to make the soil suitable for plant growth. In OMAFRA (Ontario Ministry of Agriculture, Food and Rural Affairs), fertilizer recommendations chart to optimize plant growth was used to obtain the amount of lime required for the soil. The results show that, according to OMAFRA fertilizer recommendations chart, the following amounts of limestone $2 \mathrm{~kg}, 2 \mathrm{~kg}$ and $1.9 \mathrm{~kg}$ per $\mathrm{m}^{2}$ of soil should be added to the soil acidified with electrokinetic, hydrochloric and nitric acids, respectively. The soil acidified with citric acid needs significantly higher amount of lime. More important, the results showed that the amount of phosphorus on the soil treated with electrokinetics was $11.7 \mu \mathrm{g} / \mathrm{g}$ compared with $3.5 \mu \mathrm{g} / \mathrm{g}$ and $6.6 \mu \mathrm{g} / \mathrm{g}$ hydrochloric acid and nitric acid, respectively. A highly phosphorous content is beneficial for soil fertility and plant growth. Despite the higher amount of phosphorus in soil acidified with citric acid $(14.4 \mu \mathrm{g} / \mathrm{g})$, substantially larger amount of lime is required for the soil to achieve the optimum $\mathrm{pH}$ for plant growth. The lower amount of $\mathrm{K}, \mathrm{Mg}, \mathrm{Na}$ and $\mathrm{Ca}$ in the soil treated with electrokinetic remediation can be attributed to the movement of these cations by electroosmosis and electromigration. It worth mentioning that there was no copper removal from the soil samples treated with acids. Therefore, it can be concluded that the soil treated with electrokinetic remediation is likely to regain more of its fertility characteristics compared to the soil samples treated with acids.

Table 5 Parameters for soil fertility and plant growth.

\begin{tabular}{llllrllll}
\hline \multirow{2}{*}{ Soil treated by } & $\mathrm{pH}$ & Buffer $\mathrm{pH}$ & Limestone $\left(\mathrm{kg} / \mathrm{m}^{2}\right)$ & Olsen $\mathrm{P}(\mu \mathrm{g} / \mathrm{g})$ & \multicolumn{4}{c}{ Ammonium acetate extractable $(\mu \mathrm{g} / \mathrm{g})$} \\
\hline Hydrochloric acid & 2 & 4.7 & 20 & 3.5 & 156.9 & 487.7 & 193.8 & 875 \\
Citric acid & 2.3 & 3.1 & $>20$ & 14.4 & 164.3 & 400.9 & 153.8 & 718 \\
Nitric acid & 2.5 & 5.4 & 19 & 6.6 & 163.4 & 470.1 & 188.4 & 855 \\
Electrokinetics & 2 & 5 & 20 & 11.7 & 70.4 & 40.4 & 20.9 & 139 \\
\hline
\end{tabular}




\section{Conclusions}

This experimental study investigated the adsorption and desorption characteristics of plainsman clay soil using copper. Desorption and removal of copper by electrokinetic remediation was also investigated and discussed. The fertility parameters for soil acidized with electrolysis reactions and three acids were compared. The results show that:

(1) Adsorption of copper by the soil is proportional to the copper concentration in the solution and Langmuir equation represents the adsorption isotherm of the soil;

(2) Desorption of copper from the soil increases with the increase of copper concentration in the soil and the decrease in $\mathrm{pH}$;

(3) Electrolysis reactions reduced the $\mathrm{pH}$ of the soil near the anode to 2.1 and increased the $\mathrm{pH}$ at the vicinity of the cathode to 8.9 ;

(4) Electrokinetic remediation removed $86 \%$ of copper from soil near the anode $(\mathrm{pH}$ of 2.1$)$, while $76.6 \%$ of copper was removed in the desorption test with $\mathrm{pH}$ of 2 ;

(5) The fertility and plant growth characteristics of soil near the anode after electrokinetic remediation were superior to characteristics of soil samples acidized with acids.

\section{Acknowledgments}

This research was funded by NSERC (Natural Sciences and Engineering Research Council of Canada).

\section{References}

[1] B. Berkowitz, I. Dror, B. Yaron, Contaminant Geochemistry: Interactions and Transport in the Subsurface Environment, Springer, Heidelberg, 2008.

[2] A. Thompson, K.W. Goyne, Introduction to the sorption of chemical constituents in soils, Nature Education Knowledge 4 (4) (2012) 7.

[3] H.B. Bradl, Adsorption of heavy metal ions on soils and soils constituents, Journal of Colloid and Interface Science 277 (1) (2004) 1-18.
[4] R.E. Reed, P.C. Carriere, J.C. Thompson, J.H. Hatfield, Electrokinetic (EK) remediation of a contaminated soil at several $\mathrm{Pb}$ concentrations and applied voltages, Journal of Soil Contamination 5 (2) (1996) 95-120.

[5] J. Wu, D.A. Laird, M.L Thompson, Sorption and desorption of copper on soil clay components, Journal of Environmental Quality 28 (1) (1999) 334-339.

[6] A.D. Stone, J.C. O’Shaughnessy, Sorption, desorption and leaching transport of heavy metals in soils common to New England, Contaminated Soils, Sediments and Water: Science in the Real World 9 (9) (2005) 189-249.

[7] A. Dube, R. Zbytniewski, T. Kowalkowski, E. Cukrowska, B. Buszewski, Adsorption and migration of heavy metals in soil, Polish Journal of Environmental Studies 10 (1) (2001) 1-10.

[8] H.B. Bradl, Encyclopaedia of Surface and Colloid Science, T. Hubbard (ed.), Dekker, New York, 2002.

[9] V.J.G. Houba, T.M. Lexmond, I. Novozamsky, J.J. van de Lee, State of the art and future developments in soil analysis for bioavailability assessment, The Science of Total Environment 178 (1996) 21-28.

[10] T.M. Lexmond, A contribution to the establishment of safe copper levels in soil, in: P.L. Hermite, J. Dehandschutter (eds.), Copper in Animal Waste and Sewage Sludge, Reidel, Dordrecht, Commission of the European Communities report, EUR, 1981, pp. 162-183.

[11] A. Kabata-Pendias, H. Pendias, Trace Elements in Soils and Plants, 3rd ed., CRC (Chemical Rubber Company) Press, Boca Raton, FL (Florida), 2001.

[12] V.P. Evangelou, Environmental Soil and Water Chemistry: Principles and Applications, John Wiley \& Sons, Inc., NY, 1998.

[13] J. Virkutyte, M. Sillanpaa, P. Latostenmaa, Electrokinetic soil remediation-critical overview, Science of the Total Environment 289 (1-3) (2002) 97-121.

[14] S.H. Yuan, Z.M. Xi, Y. Jiang, J.Z. Wan, C. Wu, Z.H. Zheng, et al., Desorption of copper and cadmium from soils enhanced by organic acids, Chemosphere 68 (7) (2007) 1289-1297.

[15] I. Atanassova, M. Okazaki, Adsorption-desorption characteristics of high levels of copper in soil clay fractions, Water Air and Soil Pollution 98 (3-4) (1997) 213-228.

[16] I.R. Phillips, D.T. Lamb, D.W. Hawker, E.D. Burton, Effects of $\mathrm{pH}$ and salinity on copper, lead and zinc sorption rates in sediments from Moreton Bay, Australia, Bulletin of Environmental Contamination and Toxicology 73 (6) (2004) 1041-1048.

[17] A.H. Oren, A. Kaya, Factors affecting adsorption characteristics of $\mathrm{Zn}^{2+}$ on two natural zeolites, Journal of Hazardous Materials 131 (1-3) (2006) 59-65. 
[18] M.M. Page, C.L. Page, Electroremediation of contaminated soils, Journal of Environmental Engineering 128 (3) (2002) 208-219.

[19] R.F. Probstein, R.E. Hicks, Removal of contaminants from soils by electric-fields, Science 260 (5107) (1993)
498-503.

[20] Y.B. Acar, J.T. Hamed, A.N. Alshawabkeh, R.J. Gale, Removal of cadmium (II) rom saturated kaolinite by the application of electrical-current, Geotechnique 44 (2) (1994) 239-254 